\title{
Shelf Life Evaluation and Comparative HPTLC Profile of Hridya Yoga Churna
}

\author{
Vidhya Unnikrishnan ${ }^{1 *}$, Karra Nishteswar ${ }^{2}$, Bhupesh R. Patel ${ }^{3}$ \\ 'Department of Dravyaguna, Ph.D Scholar, IPGT \& RA, Jamnagar, Gujarat-361008, INDIA. \\ 2Department of Dravyaguna, Ex-Professor \& Head, IPGT \& RA, Jamnagar, Gujarat-361008, INDIA. \\ ${ }^{3}$ Department of Dravyaguna, Asst.Professor, IPGT \& RA, Jamnagar, Gujarat-361008, INDIA.
}

\begin{abstract}
Background: Quality, safety and efficacy of medicines used form the backbone of every health care system. Shelf-life is the length of time, after which all substances start to degrade in their qualities and become unsuitable for consumption or sale. The saviryatavadhi of churna is considered to be 2 months according to ayurvedic classics. The use of modern packaging technology and preservatives have increased the shelf life period of ayurvedic medicines and the shelf life period of churna is 2 years according to Rule 161-B, Drugs and Cosmetics Act. To ascertain the quality, hridya yoga churna was taken up to assess its shelf life period. Methods: Accelerated stability study (includes evaluation of organoleptic and physicchemical parameters, assay of active constituents and microbial load) and Comparative HPTLC (High Performance Thin Layer Chromatography) were done to evaluate the shelf life of the Hridya yoga churna. Atomic absorption spectrophotometry was done to analyze the heavy metal content in the sample. Results and Conclusion: In the present study the shelf life
\end{abstract}

period of Hridya yoga churna is found to be 3 years and 7 months. Similar $R_{f}$ values obtained in HPTLC analysis of hridya yoga churna initially and after six months showed the minimum deterioration of the product. The presence of heavy metals namely arsenic, cadmium and lead were not detected and mercury was present within permissible limits.

Key words: Accelerated stability, Shelf life, Hridya Yoga, Churna, HPTLC.

Correspondence:

Vidhya Unnikrishnan, Depatment of Dravyaguna, IPGT \& RA, Jamnagar, Gujarat-361008, INDIA.

Phone no: 9446967950

Email: drvidya.unni@gmail.com

DOI : 10.5530/pj.2016.3.10

\section{INTRODUCTION}

Shelf life or "Saviryata avadhi" means the time period during which the potency (Virya) of a drug remains unaffected due to environmental factors or from microbial contamination. Different dosage forms have different shelf life period. Pancha vidha kashaya kalpanas (five different dosage forms) are described in therapeutic system of Ayurveda, which is further classified into upakalpanas. These include different dosage forms like Swarasa (juice), Kwatha (decoction), Kalka (paste), Churna (powder), Vati (tablet), Taila (oils), Lepa-malahara (ointment), Asava and Arista (self generated alcoholic preparations), Avaleha (linctus), Bhasma (incinerated powder), Pisti (paste) etc. Among them some have very short shelf life period, Eg. Swarasa- which is to be used immediately after preparation, and some of them have long shelf life, Eg. Asava, Arishta, Bhasma etc. The information regarding the concept of Shelf life (Saviryatavadhi) for different dosage forms are found scattered in Brhatrayi. According to Acharya Charaka a drug can be utilized for therapeutic purposes until it retains its fragrance, color, taste etc. ${ }^{1}$ During the medieval period authors attempted to compile the information regarding the concept of shelflife and Saviryata avadhi of different dosage forms are available in texts like Vangasena Samhita, ${ }^{2}$ Sharangadhara Samhita, ${ }^{3}$ Yogaratnakara ${ }^{4}$ etc. The uses of modern packaging technology and preservatives have increased the shelf life period of ayurvedic medicines. The saviryata avadhi of churna given in Sarngadharasamhita is 2 months. ${ }^{3}$ Shelf-life defined for Churna according to Rule 161-B, Drugs and Cosmetics Act is 2 years. Stability study provides evidence on how quality of a drug substance or product varies with time under influence of variety of environmental factors such as, temperature, humidity and light and also to establish a retest period for the drug substance or product and recommended storage conditions. ${ }^{5}$ Considering the developments in pharmaceutical industry an attempt has been made to evaluate the shelf life of Hridya yoga churna of Bhavamisra.

\section{MATERIALS AND METHODS}

\section{Preparation of the study drug}

The individual drugs of the classical hridya yoga were collected and identified. Individual powder microscopy was done at Pharmacognosy unit, IPGT and RA, Jamnagar to prove the authenticity of the drug. All the drugs were powdered separately and the powder was sieved through mesh size \#85. All the seven drugs were taken in equal quantity and mixed together to make the formulation. The formulation was packed in air tight food grade containers. Four containers of $50 \mathrm{~g}$ each were packed and stored in accelerated stability study chamber. Composition of the hridya yoga churna is given in Table 1 .

\section{Accelerated stability study}

Accelerated stability study was conducted as per ICH guideline Q1. $\mathrm{A}(\mathrm{R} 2) .{ }^{6}$ Samples were stored at $40^{\circ} \mathrm{C} \pm 2^{\circ} \mathrm{C}$, and $75 \pm 5 \%$ relative humidity. Samples were withdrawn at the intervals of 1,3 , and 6 months. Basic analytical parameters including loss on drying at $110^{\circ} \mathrm{C},{ }^{7}$ ash value, ${ }^{8} \mathrm{pH}$ value, ${ }^{9}$ water soluble extractives, ${ }^{10}$ methanol soluble extractives, ${ }^{11}$ percentage of tannins, ${ }^{12}$ alkaloids ${ }^{13}$ and saponins ${ }^{14}$ were evaluated at regular intervals. $10 \%$ degradation was set as the acceptable point to extrapolate the accelerated stability data. Real time aging factor 5 and 3.3 was used for extrapolation of shelf life for climatic Zone I \& II countries and climatic Zone III \& IV countries respectively. India comes under climatic zone III \& IV.

Number of months when $10 \%$ degradation was occurred was calculated using following formula:

[0 month assay value- $\{(0$ month Months when $10 \%$ degradation occurs $=\frac{\text { assay value } \times 10 / 100\}]- \text { Intercept }}{\text { Slope }}$ 
Table 1: Composition of Hridya Yoga

\begin{tabular}{cccc}
\hline Drugs & Botanical source & Part Used & Quantity \\
\hline Haritaki & Terminalia chebula Retz & Fruit rind & \\
Vacha & Acorus calamus Linn & Rhizome & \\
Rasna & Alpinia galanga (L.) Willd & Root & \\
Pippali & Piper longum Linn & Fruit & All drugs in \\
equal quantity \\
Shunthi & Zingiber officinale Roscoe & Rhizome & \\
Shathi & Hedychium spicatum Sm. in A. Rees & Rhizome & \\
Pushkaramoola & Inula racemosa Hook.f & Root & \\
\hline
\end{tabular}

Table 2: Organoleptic parameters of Hridya Yoga at different intervels

\begin{tabular}{ccccc}
\hline $\begin{array}{c}\text { Organoleptic } \\
\text { Parameters }\end{array}$ & Initial & $\mathbf{1}^{\text {st }}$ month & $\mathbf{3}^{\text {rd }}$ month & $\mathbf{6}^{\text {th }}$ month \\
\hline Taste & Pungent and Bitter & OK & OK & OK \\
Colour & Creamish & OK & OK & OK \\
Odour & Charcteristic & Charcteristic & Charcteristic & Charcteristic \\
\hline
\end{tabular}

Table 3: Physico chemical parameters of Hridya Yoga at different intervels

\begin{tabular}{ccccc}
\hline Physico chemical parameters & Initial & $1^{\text {st }}$ month & $3^{\text {rd }}$ month & $6^{\text {th }}$ month \\
\hline LOD (\%) & 9.51 & 9.24 & 11.28 & 11.79 \\
Ash Value (\%) & 4.91 & 5.18 & 4.94 & 4.46 \\
Acid Insoluble Ash (\%) & 0.63 & 0.68 & 0.65 & 0.62 \\
Water Soluble extractive (\%) & 22.33 & 23.01 & 24.11 & 24.82 \\
Alcohol Soluble extractive (\%) & 29.21 & 28.15 & 27.66 & 28.73 \\
\hline
\end{tabular}

Table 4: Assay of Active constituents of Hridya Yoga at different intervels

\begin{tabular}{ccccc}
\hline Assay of Actives & Initial & $1^{\text {st }}$ month & $3^{\text {rd }}$ month & $6^{\text {th }}$ month \\
\hline Tannin (\%) & 8.19 & 7.20 & 7.42 & 7.12 \\
Alkaloids (\%) & 0.17 & 0.16 & 0.14 & 0.14 \\
Saponin (\%) & 5.86 & 5.75 & 4.87 & 4.82 \\
\hline
\end{tabular}

Table 5: Microbial load of Hridya Yoga

\begin{tabular}{|c|c|c|c|}
\hline Microbial Test & Initial & $6^{\text {th }}$ month & $\begin{array}{c}\text { Permissible limits } \\
\text { as per WHO }\end{array}$ \\
\hline Total plate count $(\mathrm{cfu} / \mathrm{g})$ & $1447 \mathrm{cfu} / \mathrm{g}$ & $1656 \mathrm{cfu}^{*} / \mathrm{g}$ & Not more than $10^{5} / \mathrm{g}$ \\
\hline Total fungal count (cfu/g) & $94 \mathrm{cfu} / \mathrm{g}$ & $96 \mathrm{cfu} / \mathrm{g}$ & Not more than $10^{3} / \mathrm{g}$ \\
\hline Escherichia coli & Absent & Absent & $10 / g$ \\
\hline Pseudomonas aeruginosa & Absent & Absent & Absent \\
\hline Staphylococcus aureus & Absent & Absent & Absent \\
\hline Salmonella Spp. & Absent & Absent & Absent \\
\hline
\end{tabular}

* cfu-colony forming unit.

Table 6: Heavy Metal Analysis of Hridya Yoga

\begin{tabular}{ccc}
\hline Heavy Metal by AAS & Results & Permissible limits as per WHO \\
\hline Arsenic & ND (Not Detected) & Not more than $3 \mathrm{ppm}^{\star}$ \\
Lead & ND & Not more than $10 \mathrm{ppm}$ \\
Mercury & $0.217 \mathrm{ppm}$ & Not more than $1 \mathrm{ppm}$ \\
Cadmium & $\mathrm{ND}$ & Not more than $0.3 \mathrm{ppm}$ \\
\hline
\end{tabular}

${ }^{*}$ parts per million. 
Table 7: Intercept and Slope

\begin{tabular}{ccc}
\hline Parameters & Intercept & Slope \\
\hline LOD & 9.35 & 0.44 \\
Ash Value (\%) & 5.11 & 0.094 \\
Acid Insoluble Ash (\%) & 0.67 & 0.004 \\
Water Soluble extractive (\%) & 22.54 & 0.409 \\
Alcohol Soluble extractive (\%) & 28.54 & 0.042 \\
Tannin (\%) & 7.78 & 0.126 \\
Alkaloids (\%) & 0.165 & 0.005 \\
Saponin (\%) & 5.80 & 0.19 \\
\hline
\end{tabular}

Table 8: Approximate period for $10 \%$ Degradation

\begin{tabular}{cccc}
\hline Parameters & Initial & $\begin{array}{c}10 \% \\
\text { Degradation }\end{array}$ & $\begin{array}{c}\text { Months required } \\
\text { for } 10 \% \\
\text { degradation }\end{array}$ \\
\hline LOD & 9.51 & 8.559 & 1.78 \\
Ash Value (\%) & 4.91 & 4.42 & 7.35 \\
Acid Insoluble Ash (\%) & 0.63 & 0.57 & 25.75 \\
Water Soluble extractive (\%) & 22.33 & 20.10 & 5.95 \\
Alcohol Soluble extractive (\%) & 29.21 & 26.29 & 53.59 \\
Tannin (\%) & 8.19 & 7.37 & 3.25 \\
Alkaloids (\%) & 0.17 & 0.15 & 2.4 \\
Saponin (\%) & 5.86 & 5.27 & 2.77 \\
Mean Months & & & 12.855 Months \\
\hline
\end{tabular}

Table 9: Extrapolation of Shelf life

\begin{tabular}{ccccc}
\hline \multirow{2}{*}{ Drug } & $\begin{array}{c}\text { Mean Months } \\
\text { for } \mathbf{1 0 \%}\end{array}$ & Multiplication & \multicolumn{2}{c}{ Shelf life } \\
\cline { 3 - 5 } degradation & Factor & Months & Years \\
\hline 12.855 & 3.33 & 42.81 & 3 Years 7 Months \\
\hline
\end{tabular}

\section{Heavy metal Analysis}

Heavy metal analysis was performed using Atomic absorption sprectrophotometer as per the methods described in WHO guidelines. ${ }^{15}$ Atomic absorption spectroscopy (AAS) is a spectroanalytical procedure for the quantitative determination of chemical elements using the absorption of optical radiation (light) by free atoms in the gaseous state.

\section{Microbial load}

Estimation of Microbial load was carried out as per standard procedure mentioned in Indian Pharmacopoeia initially and at 6 months. It included Total bacterial count, Total Fungal Count, Presence of Escherichia coli, Salmonella species, Pseudomonas aeruginosa and Staphylococcus aureus. Pure culture of Escherichia coli (NCIM: 2065; ATCC: 8739), Salmonella Spp. (NCIM: 2257 NCTC: 6017), Pseudomonas aeruginosa (ATCC 9027), Staphylococcus aureus (ATCC 6358) were obtained from NCIM Pune. The media used for the microbial limit test were of HiMedia Pvt. Ltd.

\section{HPTLC Analysis}

The HPTLC (High Performance Thin Layer Chromatography) finger print profile of methanolic extract of Hridya yoga was taken on aluminium plate coated with silica gel 60 F254 (E. Merck) as adsorbent and employing CAMAG Linomat 5 applicator. The mobile phase used was Toluene: Ethyl acetate: Formic acid (10:3:1). For derivatization Anisal-

\begin{tabular}{cc}
\multicolumn{3}{c}{ Table 10: $\mathbf{R}_{\mathbf{f}}$ at $\mathbf{2 5 4} \mathbf{~ n m}$} \\
\hline Track 1 & Track 2 \\
\hline 0.14 & 0.14 \\
0.32 & 0.32 \\
0.46 & 0.46 \\
0.61 & 0.61 \\
0.75 & 0.75 \\
0.82 & 0.82 \\
0.96 & 0.96 \\
\hline
\end{tabular}

\begin{tabular}{cc}
\multicolumn{2}{c}{ Table 11: $\mathbf{R}_{\mathbf{f}}$ at $\mathbf{3 6 6} \mathbf{~} \mathbf{m}$} \\
\hline Track 1 & Track 2 \\
\hline 0.14 & 0.14 \\
0.32 & 0.32 \\
0.38 & 0.38 \\
0.42 & 0.42 \\
0.46 & 0.46 \\
0.52 & 0.52 \\
0.69 & 0.69 \\
0.75 & 0.75 \\
\hline
\end{tabular}

\begin{tabular}{cc} 
Table 12: $\mathbf{R}_{\mathbf{f}}$ at $\mathbf{5 4 0} \mathbf{~ n m}$ \\
\hline Track 1 & Track 2 \\
\hline 0.07 & 0.07 \\
0.14 & 0.14 \\
0.23 & 0.23 \\
0.32 & 0.32 \\
0.46 & 0.46 \\
0.52 & 0.52 \\
0.61 & 0.61 \\
0.75 & 0.75 \\
0.90 & 0.90 \\
0.96 & 0.96 \\
\hline
\end{tabular}

dehyde Sulphuric acid reagent was used and heated at $100 \pm 5^{\circ} \mathrm{C}$ till the spots appeared. The plate was dried and visualized under UV $254 \mathrm{~nm}$, $366 \mathrm{~nm}$ and $540 \mathrm{~nm}$. HPTLC finger prints were taken initially and after 6 months.

\section{RESULTS AND DISCUSSION}

The main purpose of conducting stability testing of pharmaceutical products is to ensure the efficacy and quality of active compounds in product and to establish shelf life or expiry period. No considerable changes were observed in organoleptic characters (Table 2) and microbial load (Table 5) of the Hridya yoga churna even after 6 months. Results of different physico-chemical parameters (Table 3 ) and active constituent assays (Table 4) were taken in consideration to evaluate intercept and slope (Table 7). Extrapolated shelf life of Hridya yoga Churna (Table 9) was calculated with $10 \%$ degradation rate (Table 8 ) from physicochemical parameters at accelerated condition $40^{\circ} \mathrm{C} \pm 2$ and $75 \% \pm 5 \mathrm{RH}$. On the basis of available data from accelerated stability study, it can be extrapolated that shelf life of Hridya yoga Churna is 42.81 months (3.07 years) for countries which come under climatic zone III \& IV.

Ayurvedic medicines were alleged to contain heavy metals and for the purpose of establishing the safety and efficacy, heavy metal analysis of the Hridya yoga churna was carried out (Table 6). The presence of arsenic, lead and cadmium were not detected in the Hridya yoga churna. Even though Mercury was detected (.217 ppm), it was within the permissible limits.

HPTLC finger print studies of methanolic extract of Hridya yoga were carried out and chromatogram was developed and detected using the UV visible chamber, initially and after 6 months. Seven spots were identified at UV $254 \mathrm{~nm}$ in the chromatogram as depicted in Figure 1 and 2. The corresponding $R_{f}$ values of the seven components are $0.14,0.32,0.46$, $0.61,0.75,0.82,0.96$ (Table 10). Eight spots were identified at $366 \mathrm{~nm}$ 


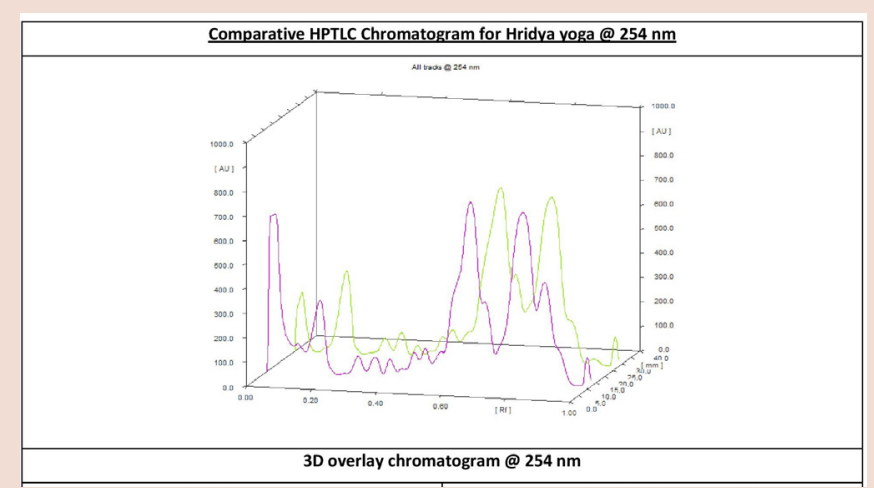

Figure 1: Comparative HPTLC Chromatogram for Hridya yoga at $254 \mathrm{~nm}$.

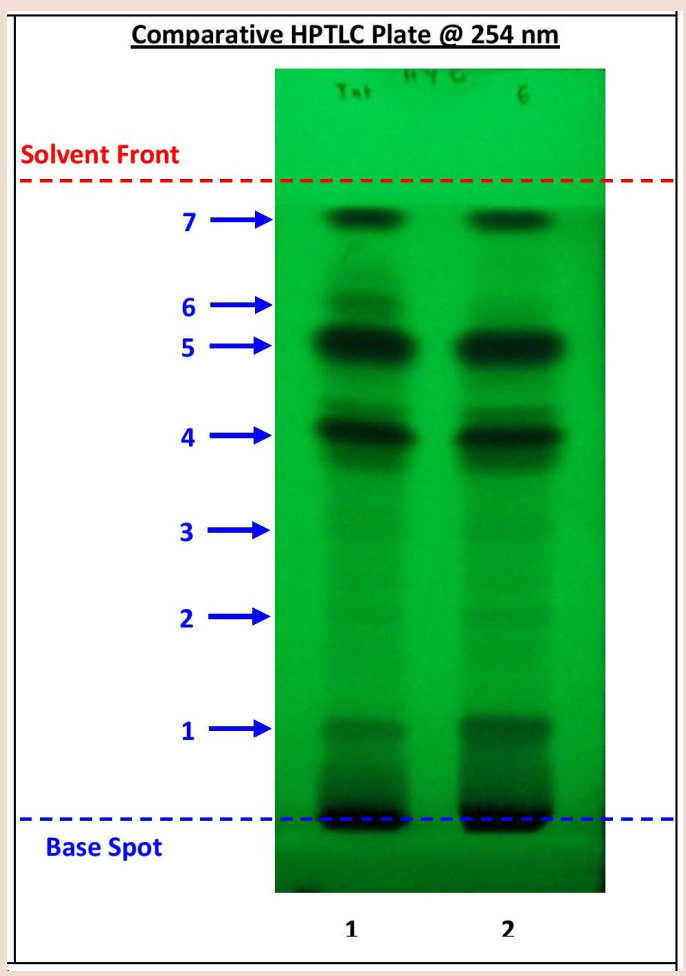

Figure 2: Comparative HPTLC plate at $254 \mathrm{~nm}$.

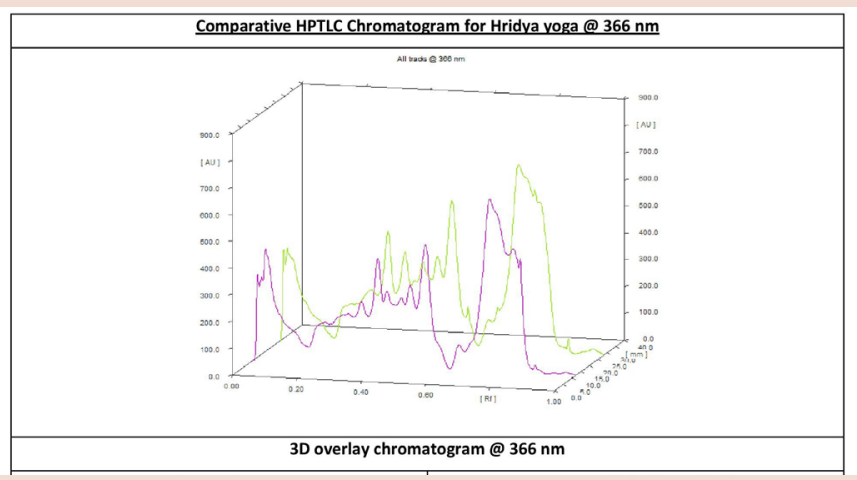

Figure 3: Comparative HPTLC Chromatogram for Hridya yoga at $366 \mathrm{~nm}$.

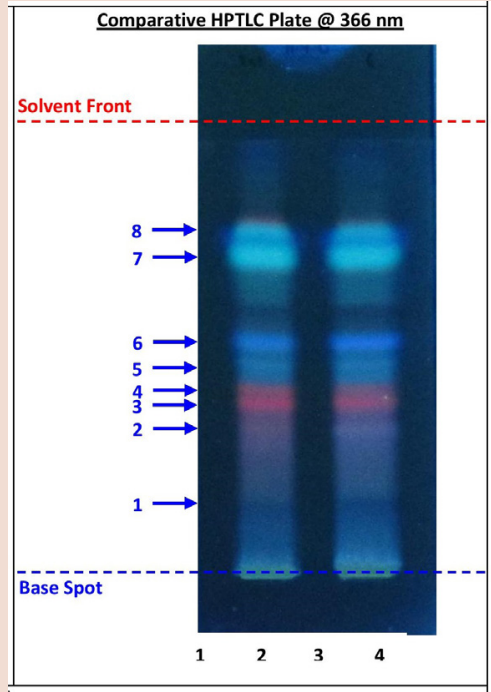

Figure 4: Comparative HPTLC plate at $366 \mathrm{~nm}$.

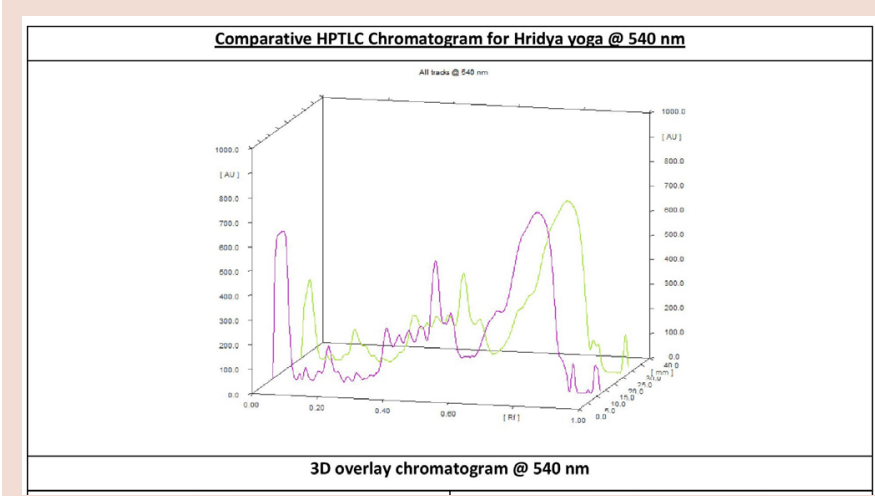

Figure 5: Comparative HPTLC Chromatogram for Hridya yoga at $540 \mathrm{~nm}$.

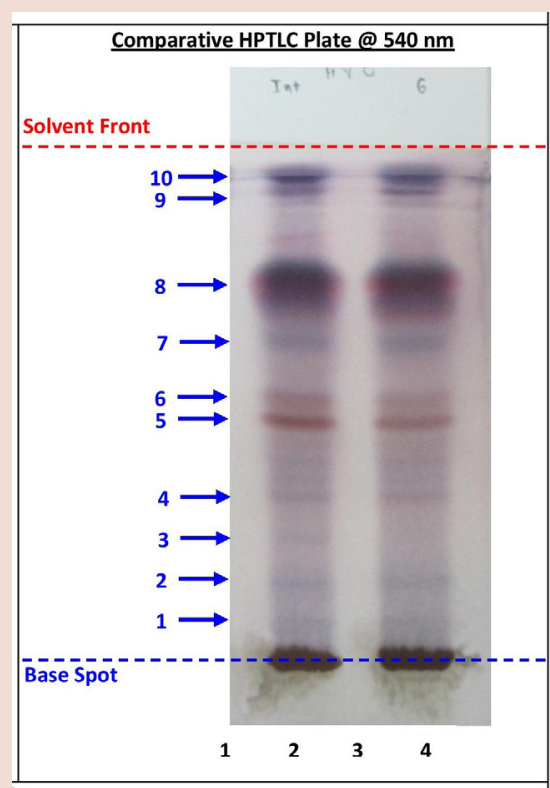

Figure 6: Comparative HPTLC plate at $540 \mathrm{~nm}$. 
(Figure 3 and 4). The corresponding $\mathrm{R}_{\mathrm{f}}$ values are $0.14,0.32,0.38,0.42,0.46$, $0.52,0.69,0.75$ (Table 11). Ten spots were identified at $540 \mathrm{~nm}$ (Figure 5 and 6). The corresponding $\mathrm{R}_{\mathrm{f}}$ values are $0.07,0.14,0.23,0.32,0.46,0.52$, $0.61,0.75,0.90,0.96$ (Table 12). All the spots identified in the hridya yoga extract initially were identified at six months also which shows the minimum deterioration of the product.

\section{CONCLUSION}

Shelf-life defined for Churna at Rule 161-B, Drugs and Cosmetics Act is 2 years. In the present study the quality of Hridya yoga churna is assessed by evaluation of shelf life. On the basis of the accelerated stability study conducted the shelf life period of Hridya yoga churna is found to be 3 years and 7 months. Similar $R_{f}$ values obtained in HPTLC analysis of hridya yoga churna initially and after six months showed the minimum deterioration of the product. The presence of heavy metals namely arsenic, cadmium and lead were not detected and mercury was present within permissible limits.

\section{ACKNOWLEDGEMENT}

Vasu Research Centre, Vadodara. Dr Galib. Asst. Professor, Dept.of Rasasastra \& Bhaishajyakalpana, IPGT and RA, Jamnagar.

\section{CONFLICT OF INTEREST}

The author decalre no conflict of interest.

\section{REFERENCES}

1. Agnivesha, Caraka, Drindhabala. Caraka Samhita, Siddhi Sthana, Vaman Virechana Vyapata Adhyaya, 6/16, edited by Yadavji Trikamji Acharya, reprint ed.

Chaukhambha Orientalia, Varanasi, 2011; 704.

2. Vangasen. Vangasen Samhita, Jwara Chikitsa 1/810. Commentatory by Shaligram GV, $1^{\text {st }}$ ed. Khemraj Shrikrishnadass Publication, Mumbai, 2003;73.

3. Sharangadhara. Sharangadhara Samhita, Poorva Khanda, $1 / 55$, edited by Parashuram Shastri, $4^{\text {th }}$ ed. Choukhamba Orientalia, Varanasi, 2000; 14

4. Anonymous. Yogaratnakara, Jwara Chikitsha, edited by Shastri L, $1^{\text {st }}$ ed. Chaukhamba Sanskrita Samsthana, Varanasi, 2005; 203.

5. Bankoti K, Rana MS, Bharadwaj MK. Accelerated stability study of herbal capsules. IOSR Journal of Pharmacy. 2012;2(5):1-6.

6. Anonymous. ICH Harmonised Tripartite Guideline. Stability testing of new drug substances and products-Q1A (R2). 2003

7. Anonymous. Indian Pharmacopeia, Vol. II, Appendix 8 (8.6). New Delhi:Govt. of India, Ministry of Health and Family Welfare, The Controller of Publication: 1996. pp. A-89.

8. Anonymous. The Ayurvedic Pharmacopoeia of India., Vol. VI, Part 1, Appendix-2 (2.2.3). $1^{\text {st }}$ ed. New Delhi: Govt. of India, Ministry of Health and Family Welfare; 2008. pp. 242.

9. Anonymous. Indian Pharmacopeia. Vol. II, Appendix 8 (8.11). New Delhi: Govt. of India, Ministry of Health and Family Welfare, The Controller of Publication 1996. pp. A-95.

10. Anonymous. The Ayurvedic Pharmacopoeia of India, Vol. VI, Part 1, Appendix-2 (2.2.8). $1^{\text {st }}$ ed. New Delhi: Govt. of India: Ministry of Health and Family Welfare; 2008. pp. 243.

11. Ibidem. The Ayurvedic Pharmacopoeia of India, Vol. VI, Part 1. Appendix-2 (2.2.7). pp. 243

12. Rajpal V. Standardization of Botanicals Vol 1. Eastern Publishers New Delhi India. 2002;pp.247.

13. Rajpal V. Standardization of Botanicals. Vol 1. Eastern Publishers New Delhi India. 2002;pp. 256

14. Rajpal V. Standardization of Botanicals. Vol 1 Eastern Publishers New Delhi India. 2002;pp. 226.

15. Geneva: World Health Organization; 1998. Quality Control Methods for Medicinal Plant Materials; pp. 25-2.

\section{PICTORIAL ABSTRACT}

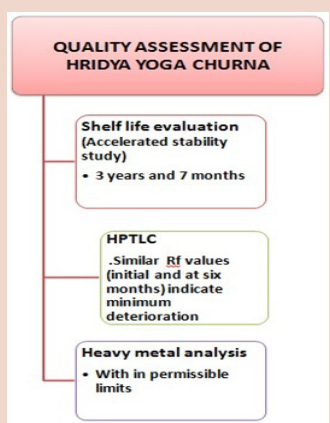

\section{SUMMARY}

- The quality of Hridya yoga churna was evaluated by assessment of shelf life.

- On the basis of the accelerated stability study conducted, the shelf life period of Hridya yoga churna is found to be 3 years and 7 months

- Similar $R_{f}$ values in HPTLC analysis(initial and at six months) also supports the findings.

\section{ABOUT AUTHORS}

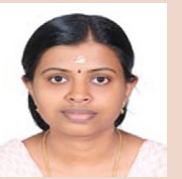

Vidhya Unnikrishnan: Is presently a PhD Scholar in the Department of Dravyaguna, IPGT \& RA, Jamnagar. Her research interest is in the area of cardiology in Ayurveda. Earlier she has worked as lecturer in the Dravyaguna Department, Govt. Ayurveda College, Thiruvananthapuram. She has published several articles in international and national journals and presented several scientific papers at national and international seminars. 